\title{
THE INFLUENCE OF CELEBRITY ENDORSEMENT IN INSTAGRAM TOWARDS CUSTOMER BEHAVIOR AND PURCHASE INTENTION IN HEALTHY FOOD DIET BUSINESS
}

\author{
Rendika Nugraha ${ }^{1}$, Kunthi A. Kusumawardani ${ }^{2}$, Vinda Octavianie ${ }^{3}$ \\ ${ }^{1}$ President University, rendika@president.ac.id \\ ${ }^{2}$ President University, kunthi.kusumawardani@president.ac.id \\ ${ }^{3}$ President University, vindaoctavianie @ gmail.com
}

\begin{abstract}
ABSTRAK
Gaya hidup sehat telah menjadi pilihan dalam masyarakat khususnya di kota besar dimana orang cenderung lebih sadar akan pentingnya mengonsumsi makanan sehat dan mengimplementasikan gaya hidup sehat. Kondisi ini mempunyai dampak positif bagi pelaku bisnis yang menjalankan usaha di bidang makanan dan minuman, khususnya yang menggunakan pendekatan makanan sehat. DI masa sekarang, ponsel pintar dan tablet telah menjadi bagian dari kehidupan seseorang dan tidak bias dipisahkan dari kehidupan sehari-hari. Didasarkan kepada gaya hidup sehat dan gaya hidup teknologi, 3 Skinny Minnies muncul sebagai salah satu bisnis yang menyediakan makanan sehat kepada pelanggannya. Dan memanfaatkan media sosial sebagai kanal distribusi seperti Instagram untung mempromosikan produk. Dalam mempromosikan gaya hidup sehat dengan menyediakan makanan sehat, 3 Skinny Minnies secara konsisten memanfaatkan selebriti untuk menjadi konten di Instagram mereka. Penelitian ini menganalisa efektifitas selebriti sebagai pendukung dalam mempengaruhi niat membeli melalui sikap terhadap merk menggunakan pendakan kuantitatif yang data primernya dikumpulkan dari responden melalui kuesioner online. Penelitian ini menggunakan 274 responden sebagai ukuran sample dan melalui analisa validitas dan reliabilitas yang diproses melalui perangkat lunak statistic menggunakan factor analysis dan Structural Equation Modeling. Berdasarkan analisa data, ditemukan bahwa selebriti mempunyai pengaruh yang rendah kepada niat membeli meskipun sikap terhadap merk mempengaruhi pelanggan secara signifikan. sikap terhadap merk dalam kasus ini mempengaruhi pelanggan secara signifikan dan mempunyai pengaruh langsung terhadap niat membeli. Jadi, untuk memenangkan kompetisi, sangat penting untuk 3 Skinny Minnies untuk memperbaiki promosi produknya sehingga aktivitas tersebut dapat lebih efektif dalam menambah pemasukan.
\end{abstract}

Kata Kunci : Dipromosikan Selebriti, Sikap terhadap merek, Niat membeli .

\section{ABSTRACT:}

Healthy life style has become a choice in the society especially in the big city where people tend to aware about the importance of consuming healthy food and implement healthy life style. This condition has a positive impact for those who run the business in food and beverage business especially with healthy food approach. Nowadays, smartphone or tablet already becomes part of people life that cannot be separated in daily activity. Driven by healthy life style and technological life style, 3 Skinny Minnies appears to be one of the player in providing healthy food to its customer and utilizing social media as distribution channel such as Instagram to promote their product. In promoting healthy life style by providing healthy food, 3 Skinny 
Minnies consistently utilize celebrity endorsement to become content of Instagram feeds. This research analyzes the effectiveness of celebrity as endorser in influencing purchase intention by attitude toward the brand using quantitative approach which, the primary data were collected from the respondents through online questionnaire. There were 274 respondents as a sample size of the research and through validity and reliability analysis that processed by statistical software using factor analysis and structural equation modeling. Based on the data analysis, it is found that celebrity endorsement has low influence on purchase intention even though the attitude toward the brand has significantly influence the customer. Hence, attitude toward the brand in this case has a direct influence on purchase intention. Thus, in order to win the competition, it is important to improve the way 3 Skinny Movies in promoting the products, so that the activities will be more effective in generating revenue.

Keywords: Celebrity Endorsement, Attitude toward the brand, Purchase intention.

\section{A. Introduction}

In Indonesia, many people start to have a healthy life style by having healthy activity such as exercise with the combination of healthy food whether with menu combination or adjusting their dietary habit to be healthier. Based on data from World Health organization (WHO), Indonesia ranked in top five for countries in the world with highest diabetes range (WHO, 2016). Furthermore, according to the latest data released from WHO, 7,18\% of deaths in Indonesia were caused by diabetes mellitus (worldlifeexpentancy.com, 2015). Such condition that caused by diabetes mellitus believed as the right reason for people to shift to healthy life style. In dietary habit itself, there are five types of diet that lead to healthy life style such as Mayo diet, Paleo diet, Alkaline diet, food combining, and also clean eating (Kusumangingrum, 2015). People claim that go through those dietary habit in order to lose weight and maintain the calories inside the body. Considering the situation where people tend to shift to healthy life style, there are many business players emerge in providing healthy food with less salt and calories. 3 Skinny Minnies is one of the healthy food provider based in Jakarta that provide healthy food wrapped in a diet program that helps customers to live healthy by having healthy food. In realizing their mission, 3 Skinny Minnies provides 5 days diet program with menu combination that has been set up by the chef to accommodate customer needs in having healthy foods.

Nowadays, social media already recognized as one of the most powerful marketing tools, with wider outreach and considerably low cost (sexsmith \& Angel, 2012). Latest survey by jajak 
pendapat app (blog.jakpat.net) about Indonesia social media trend Q1 2017 shows that Facebook is in number one as the most social media used by people followed by Instagram, Path, Twitter and Linkedin. However, Instagram is the most preferred social media for shopping purpose (blog.jakpat.net).

3 Skinny Minnies utilizes online channel as their sales channel which are Instagram and Website. In Instagram, 3 Skinny Minnies fill the content with product picture, promotion and also celebrity endorsement such as Dian Sastro Wardoyo who known as Indonesian actress who has more than 5 million followers of her Instagram account (@therealdisastr) and promoting healthy lifestyle as well by endorsing healthy based product and also become brand ambassador of several consumer goods product. In the website, 3 Skinny Minnies more focus on detail information about their product and offer as well as price information of their package. Since 3 Skinny Minnies utilizes Instagram as their main channel to interact with customer and potential customers with aspiration that target customers attracted to visit their website and purchase 3 Skinny Minnies products. However, it is not an easy task to make Instagram as an effective channel since the account should also obtain many followers that ought to be their potential target customers, that is why 3 Skinny Minnies utilizes Dian Sastro Wardoyo as endorser of their product in order to attract target customer considering frequent activity of the endorser in the Instagram and number of followers that the endorser has as well as image that the endorser posses in the eye of society.

Based on the current situation, This research aims to study and analyze the influence of existing 3 Skinny Minnies celebrity endorsement in driving customer's purchase intention towards the product that offered. In order to make the research more focus and directive, three aspects will be evaluated regarding celebrity endorsement such as; the source of credibility, the source of attractiveness model, and product congruency as stated by previous research (Ohanian, 1990; Shin, 2010; Mngan, 2013; Jatto, 2014).

\section{B. Literature Review}

\section{Celebrity Endorsement}

Celebrity endorsement is one of the strategies that commonly used by business player as one of the promotional tools. McCracken stated that celebrity endorser in terms of public figure whose well known and recognized in the eye of public often utilized by business player to boost up 
business reputation. There are several forms of endorsement that commonly practiced which are giving expert opinions, become a spokesperson for certain product, or even only associated to with a product (McCracken 1987; Seno and Lukas, 2007). Utilization of celebrity as endorser will increase customer brand awareness, grab customer attention, as well as make the advertisement memorable which improving brand recall (Ahmad \& Rafique, n.d). There are certain parameters that determine compatibility between brand image and celebrity such as popularity, physical attractiveness, credibility, prior endorsements, celebrity user status towards the brand, profession, celebrity's fit with brand image, target audience of celebrity, celebrity associated value, acquisition cost, product match, and controversy risk.

\section{Source of Credibility and Attractiveness Model}

Source of credibility is a term that used to indicate point out positive characteristic by the communicators that will influence message acceptance and receiver's trust (Kutthakaphan, 2013). Credibility is important matters for celebrity since celebrity perceived as credible source of information (Goldsmith et al, 2000; Hoekman, n.d). In order to measure effectiveness of celebrity endorsement, Hovland et. al. developed a source credibility model and attractiveness model in 1953. The measurement consist of expertise and trustworthiness, and also the attractiveness model which emphasizes on the character of attractiveness which nowadays still utilized by the researchers (Cheung et. al., 2009; Methaq, 2011; Umeogu, 2012; McCroskey, 2015). Ohanian supported source of credibility model and attractiveness model in 1990 on her research and developed deliberation source of credibility model with multi dimensional explanatory model by developed a scale that consist of three components which are, trustworthiness, expertise and attractiveness. Many recent studies utilize the three dimension of Ohanian to measure effectiveness of celebrity endorsement (Lord \& Putrevu, 2009; Spry et al.., 2011; Hussain et al., 2012; Wei \& Lu, 2013; Muda, Musa, Mohamed, \& Borhan, 2014). There are 15 points that constructed as the reliable and consistent measurement scale to the source of credibility model by Ohanian. Also, the realibility and validity of those components have been tested with a large pool of item and therefore those 15 semantic differential scale is determined as qualified for future research (Kutthakaphan \& Chokesamritpol, 2013). Those 15 points were set up by evaluating three main aspects which are, Trustworthiness, expertise, and attractiveness. Trustworthiness refers to honest, integrity and believability of the endorsers and those believed in 
supporting the influence process to the customers ' belief, opinion, attitude, as well as purchasing behavior (Ohanian 1991; Edrogan et al., 2001; Oyeniyi, 2014). Ahmed (2014) used Ohanian's 15 point source of credibility model scale as a tool to measure the level of trustworthiness of celebrity endorser in his research. There are 5 points of sub categories from Ohanian's trustworthiness which are dependable, reliable, honest, sincere, and trustworthy. Expertise defined as the extent to which a communicator is perceived to be source of valid requirement of the object or issue (Muda et al., 2015).

Aaker and Meyers argued that customers are more convinced to purchase a product the endorsed by well informed celebrity or whose profession is related to the brand function. Also, the level of persuasiveness by celebrity is likely enhanced by the expertise that possessed by those celebrity (Oyeniyi, 2014). Therefore, through Ohanian's 15 point source credibility model scale, expertise measured by 5 sub category in semantic scale which are, expert, experienced, knowledgeable, qualified and skilled. Erdogan stated that the concept of attractiveness acquired by several items such as intellectual skills, personality attraction, life styles, physical performances, and skills of endorsers (Adani, 2015). McGuire also developed the source of attractiveness model that depends on three important dimensions such as similarity, likeability, and familiarity in his research on 1985 and still used by researchers nowadays (Braunstein, 2006; Atay, 2011; Peetz, 2012; Hugosson, 2014; Fang, 2015). Previous study by Clow, James et al., (2006) has shown that the attractiveness may develop a positive attitude toward purchase intention which supported by visual advertisement. Ohanian found that attractiveness can positively influence the customers behavior toward products and services rather than those which endorsed by unattractive figure (Hasan \& Jamil, 2014).

Therefore, celebrity attractiveness perceived to posses positive influence on products or services that they represent. Thus, Ohanian specified attractiveness dimensions through 15 point source of credibility model scale and measured by 5 sub categories in semantic scale such as, attractive, classy, beautiful, elegant and sexy.

Table 1. 15 Point Source of Credibility Model

Source: (Ohanian, 1990)

\begin{tabular}{|c|c|c|}
\hline TRUSWORTHINESS & EXPERTISE & ATTRACTIVENESS \\
\hline Not Dependable - & Not Expert - & Unattractive - \\
\hline
\end{tabular}




\begin{tabular}{|c|c|c|}
\hline Dependable & Expert & Attractive \\
\hline Dishonest - Honest & $\begin{array}{c}\text { Inexperienced - } \\
\text { Experienced }\end{array}$ & Not Classy - Classy \\
\hline Unreliable - Reliable & $\begin{array}{c}\text { Unknowledgeable } \\
- \text { Knowledgeable }\end{array}$ & Ugly - Beautiful \\
\hline Insincere - Sincere & $\begin{array}{c}\text { Unqualified - } \\
\text { Qualified }\end{array}$ & Plain - Elegant \\
\hline $\begin{array}{c}\text { Untrustworthy - } \\
\text { Trustworthy }\end{array}$ & $\begin{array}{c}\text { Unskilled - } \\
\text { Skilled }\end{array}$ & Not Sexy - Sexy \\
\hline
\end{tabular}

\section{Celebrity and Product Congruent}

Persuasiveness of celebrity endorsement defined by Kahle and Homer as a function of how well the endorser's image fits with the product's image or can be simplified that celebrity endorsement is persuasive enough when the endorser has a certain fit with product that he or she represents in terms of image and better known as "match up hypothesis" (Nung et al. 2011). Through this concept, there should be a match and congruency between the image of celebrity endorser with brand and product in order to generate effective advertising through celebrity endorser. Thus, there are two schemas of congruity and in congruity that considered in this matter.

In previous research by Mandlers (1989), based on previous information that have been received in customers' memory, customers expectations can be identified by the schema congruity as the level of new information that spread to the customers. Meanwhile, Meyers \& Tybot's study on 1989 stated that schema of congruity established when there is a relevance among the endorser's image and product's image in the eye of customers, which can be built through the congruity between endorser and product. Thus, Positive responses can be created because there is a match between advertisement with customers' expectation and help customers to predict future outcomes of product (Nung et al., 2011).

In the other hand, Desai \& Gentruck (1995) as cited in Nung et al., (2011) defined that any information which is not reliable with the previous expectation by the customers as schema incongruity. Because of that, schema incongruity happens when the image of celebrity does not match with product image, then more efforts would needed to resolve the incongruity. Therefore, previous researches that have been done by Kamins \& Gupta (1994); Kotler et al., (2005) and 
Amos (2008) found that the desired level of believability and effectiveness is a result of highest congruity between the image of product and the brand compared to the lowest congruity.

\section{Meaning of Transfer Model}

Developed by McCracken (1989) the meaning of transfer model theory defined the celebrity endorsement process as a process of a meaning transfer. In this model, figure properties that possessed by the endorser should be able to be transferred to a specific product or brand that they represent, and later from the product to the customers (Löfgren \& Li, 2010). The transfer process involves celebrity, product and customers that divided into three stages which are meaning transfer process, Carrying Process, and disseminating process.

First stage, celebrity is expected to be able to deliver a meaning in depth and clever way to strengthen the product by taking the advantage of endorser popularity in the advertisement (Kutthakaphan \& Chokesamritpol, 2013). Cultural meanings that carried by the endorser in the endorsement process can determine the effectiveness of endorsement (Nhung et al., 2011). Several meanings that represent the endorsers are character, status, class, lifestyle, and charm that brought from their career path as well as society.

Second stage, when celebrity carry their meanings and image to the advertisement and transfer it to the product that they represent in order to develop image of product as well as the brand (Nhung et al., 2011). Business player need to choose celebrity endorser who able to represent product characteristics precisely and the advertisement message should also have similar characteristic between the celebrity endorser and the product (Kutthakaphan \& Chokesamritpol, 2013). Therefore, celebrity endorser and the product must have a connection in order to create high similarity that support carrying process. This condition where there are similarities between endorser and the product will create an assurance for the customer towards product and brand that represented by celebrity endorser (Löfgren \& Li, 2010).

Third and last stage, disseminating process that is claimed as the most difficult and high level of complexity compared to two previous stages (Nhung et al., 2011). In this stage, celebrity endorsement should be able to makes the properties of a product become the properties of the customers since they try to find the product with practical meanings as they put efforts on searching the meanings that they need. Product meaning cannot enter the customer's mind instantly. Towards the third stage of process, synergy between celebrity endorser and the product 
should be able to claim, interchange, care for, and use the customer good in order to posses the meaning (Löfgren \& Li, 2010). McCracken stated that celebrities have a crucial role in the final stage of meaning transfer since identity of the brand is created through the endorsement as well (Kutthakaphan \& Chokesamritpol, 2013). Thus, when customers have possessed the meaning, it couild be said that the last part of the process is accomplished (Belch \& Belch, 2009).

\section{Customer Attitude}

Attitude is a form of response that comes from human as they react to certain condition, which in extent will create cognitive, affective, and behavior as it stated by Rosenberg \& Hovland (Kutthakaphan \& Chokesamritpol 2013). Furthermore, attitude is a combination and integration of three components affect, cognition, and behavior system, which influence each other so that the entire attitude can change if there is a change in one of the component. Therefore, multi component models of attitude were developed into two dimensions, stated by Rosenberg \& Hovland (1960). First dimension is stimuli, which is categorized as independent variable, which is able to influence customers' attitude by a certain event that happen in the environment. Second is an intervening variable of attitude, which are affective, cognition, and behavior (Kutthakaphan \& Chokesamritpol, 2013). Affective include feelings in representing sensation, emotion, and impressions. Cognition is essentially consists of learning, thinking, remembering and the likeliness (Kutthakaphan \& Chokesamritpol, 2013). Behavior essentially consists of action, activities, and habits. Therefore, if the business player understands customer's attitude, it will help developing the best method to make the product more preferable in terms of customer's perspective by influencing their attitude and change the behavior.

Existence of a brand is created when there is a form of identification towards all the marketing entity such as such a product, an outlet, a service, or even a geographical place for example entire country, region, state or city obtains its own name, term, sign, symbol, design, or other specific combination of these elements (Shimp, 2010). However, there will always be a choice for customers to select appropriate product and service based on their needs even in a limited time to make a decision. The well-known and trusted brand are be able to simplify their decision making process by having effective advertisement that inspire customers to select the brand. From customer point of view, brand is such a promise, as they will purchase from well-known and trusted brand (Belch \& Belch, 2003). Driven by this situation, business player should be able to 
generate strong brand proposition of their products. All of the marketing activities and tools should provide uniformed message in order to prevent and avoid misinterpretation of the message that delivered to the customers. Brand should also be able to create gimmick as differentiator from another brand. Such interaction that made by brand and customers may lead to certain attitude toward the brand through customers' perspective, which determined by its provided quality and satisfaction (Doss, 2011; Keller, 2013). Since the judgment could be positive or negative, business player should be able to make consistent product's quality in line with its claim in the advertisement.

\section{Purchase Intention}

Purchase intention defined as that made by customers in deciding to purchase a certain brand or product (Shah et al, 2011). There are several elements that include in purchase intention such as customer's willingness to consider in buying the product, buying intention of the product in the future and repurchase decision (Rahman et al., 2012). Also, there are several stages that involve in consumer buying decision process to purchase and repurchase certain product. Consumer buying decision process explained into five processes, which are need recognition, information search, evaluation of alternatives, purchase decision, and also post purchase decision (Belch \& Belch 2003; Kotler \& Armstrong, 2010). Customers will through all process before they decide to purchase certain product or to repurchase a certain product.

\section{The Relationship between Celebrity Endorsement and Attitude toward the Brand}

Based on previous researches, it is proven that product that endorsed by well known and attractive celebrity attracts more and tend to catch more awareness from the customers compare to unknown endorser who does not posses any specialty or character. Celebrity endorsement program will influence the attitude toward the brand significantly due to image that formed to the product by celebrity endorser (Ohanian, 1990; Erdogan, 2001; Amos et al., 2008; Hasan \& Jamil., 2014). Choi \& Rifon (2012) also supported several previous researches that significant influence on customers' toward the brand compared to attractiveness is a result of congruence of the image between the celebrity endorser and the product that they represent. Furthermore, credibility of the endorser positively affect the attitude toward the brand compared to the attractiveness (Muda et al., 2014). Based on their research, it is found that congruence between celebrity and the product image that being endorsed, well product knowledge, and capable in 
delivering the meaning of the product to customers in increasing believability of endorser credibility.

\section{The Relationship between Celebrity Endorsement and Purchase Intention}

Customers' perspective regarding source of information of the product or service is essential in leading potential customer to make a purchase plan in the future. In this case, it is important to deliver same message that can be interpreted easily to the customer's mind by both endorser and the product, since the cognitive process works behind (Hasan, \& Jamil, 2014). Celebrity endorser carries certain attribute to develop the customer's buying behavior. Thus, positive attitude of the customer toward celebrity endorser will increase buying intention to the product that being endorsed (Amos et al., 2008).

\section{The Relationship between Attitude toward the Brand and Purchase Intention}

Some previous studies found that attitude toward the brand has positive and significant influence on customer purchase intention (Wahid \& Ahmed, 2008; Choi \& Rifon, 2012; Muda et al., 2014). Meanwhile, in order to increase brand awareness and create emotional connection of potential customers to support customer purchase decision, advertisement is one of the attempts that can be executed by business player (Latif \& Abideen, 2011; Mirabi et al., 2015). Feeling that developed between brand and customer in terms of pleasant impression toward the brand will develop desired attitude toward the product (Mirabi et al., 2015). Therefore, researchers intend to investigate and evaluate relationship between attitude toward and purchase intention due to support from previous researchers.

\section{Theoretical Framework}

Figure 1 Theoretical Framework

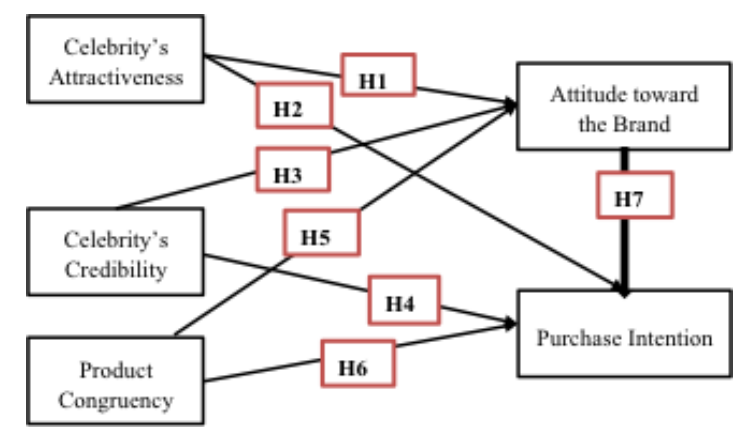


Source: Constructed by researcher from previous studies

Figure 1 shows the theoretical framework of this research. The independent variable is the dimension of celebrity endorser, which are celebrity's attractiveness (Kutthakaphan \& Chokesamritpol, 2013; Hasan \& Jamil 2014; Muda et al., 2014), celebrity's credibility (Kutthakaphan \& Chokesamritpol, 2013; Ahmed et al., 2014; Adani, 2015), and celebrity and product congruence (Choi \& Rifon, 2012; Kutthakaphan \& Chokesamritpol, 2013; Hasan \& Jamil, 2014). The mediator variable is attitude toward the brand (Wahid \& Ahmed, 2008; Choi \& Rifon, 2012; Muda et al., 2014) and the dependent variable is purchase intention. (Kumar, 2010; Choi \& Rifon, 2012; Muda et al., 2014; Adani, 2015).

\section{Hypothesis}

H1: Celebrity endorser's attractiveness has influence on attitude toward the brand on Instagram.

H2: Celebrity endorser's attractiveness has influence on purchase intention.

H3: Celebrity endorser's credibility has influence on attitude toward the brand on Instagram.

H4: Celebrity endorser's credibility has influence on purchase intention.

H5: Celebrity endorser and product congruency has influence on attitude toward the brand on Instagram.

H6: Celebrity endorser and product congruency has influence on purchase intention.

H7: Attitude toward the brand has influence on purchase intention.

\section{Research Method}

\section{Research Design}

This research was developed by applying quantitative research to test hypothesis drawn, and quantify the data in the area of celebrity endorsement, attitude toward the brand, and the purchase intention. According to Creswell (2009), using quantitative method provides quantifiable data of trends, attitude, and opinion. The objective of this research is to determine which variables are more significantly influence purchase intention through empirical data analysis. Research instrument that used in this research are questionnaire that considered as primary data collection 
method. In presenting findings from more than two variable, usage of questionnaire is allowed to have greater clarity of findings (Domegan and Eelming, 2017). Highly structured questionnaire would make a boundary for the respondents in response the questionnaire and prevent respondents to give further opinion (Czala and Blair, 1996; Domegan and Felming; 2007).

\section{Sampling Design}

Researcher selected young - adults who live in Jakarta as target population of sampling since young - adults actively using internet connection and social media, and nowadays they become potential segment in the market because of their number of population, spending amount, and their potential for future increment of purchasing parity (Kutthakaphan \& Chokesamritpol, 2013). Meanwhile, Jakarta area was chosen based on 3 Skinny Minnies operational area based in Jakarta and most of the customers are located in Jakarta area. Researcher determine number of sample based on Jackson as cited in Kline (2011) that recommends the sample size is determined by multiplying the ratio of cases $(N)$ to the number of measuring questions that require statistical calculation $(q)$ or $N \times q .20: 1$ is categorized as the ideal ratio of $N$ x $q$. This research, due to time limitation uses the 10:1 as the sample size ratio. Since this research has 27 questions $(q)$, therefore, the number of sample size would be:

$$
\begin{aligned}
\text { Sample Size } & =N \times q \\
& =10 \times 27 \\
& =27 \text { respondents }
\end{aligned}
$$

Researcher uses purposive sampling technique as one of the types of non-probability sampling where respondents are chosen specifically because they are not representative of population, however chosen because they fit some criteria which specific to the study (Domegan and Flemming, 2007). This research aimed to young - adults in age range between 18 - 35 years old, live in Jakarta, and have experience on merely observing the advertisement post from Dian Sastro Wardoyo and 3 Skinny Minnies Instagram account, interested and leave positive comment on 3 Skinny Minnies Instagram account, also the people who already purchased 3 Skinny Minnies Products. Thus, they could evaluate their perception of celebrity endorser, attitude toward the brand, and also purchase intention of 3 Skinny Minnies product. 


\section{Research Instrument}

Questionnaire of this research is divided into two sections; which first section consists of respondents' demographic characteristics. Second section consists of independent variable (celebrity endorsement, with the variable of celebrity's credibility, celebrity's attractiveness, and product congruence), and the dependent variable (attitude toward the brand, and purchase intention). Likert scale is used to obtain respondents' level of agreement by choosing one preference to specify degree of agreement. There are 7 point likert type scales have been built; Strongly Disagree (SD), Disagree (D), Disagree Somewhat (DS), Neutral (N), Agree Somewhat (AS), Agree (A), and Strongly Agree (SA). Table 2 shows questionnaire statements that used in this research, also the source and number of items of constructs used.

Table 2. Questionnaire Statements

\begin{tabular}{|c|c|c|c|}
\hline Variables & Indicators & Questions & Author \\
\hline \multirow{6}{*}{$\begin{array}{c}\text { Celebrity } \\
\text { Endorser's } \\
\text { Attractiveness }\end{array}$} & Attractive & $\begin{array}{c}3 \text { Skinny Minnies celebrity } \\
\text { endorser has an attractive } \\
\text { appearance }\end{array}$ & \multirow{6}{*}{$\begin{array}{l}\text { Ohanian (1990) } \\
\text { as cited in } \\
\text { Kutthakaphan \& } \\
\text { Chokesamritpol } \\
\text { (2013) }\end{array}$} \\
\hline & Classy & $\begin{array}{c}3 \text { Skinny Minnies celebrity } \\
\text { endorser has a classy } \\
\text { appearance }\end{array}$ & \\
\hline & Beautiful & $\begin{array}{c}3 \text { Skinny Minnies celebrity } \\
\text { endorser has a beautiful } \\
\text { appearance }\end{array}$ & \\
\hline & Elegant & $\begin{array}{c}3 \text { Skinny Minnies celebrity } \\
\text { endorser has an elegant } \\
\text { appearance }\end{array}$ & \\
\hline & Likeability & $\begin{array}{c}\text { I like the celebrity endorser of } 3 \\
\text { Skinny Minnies }\end{array}$ & \\
\hline & Familiar & $\begin{array}{c}\text { The celebrity endorser of } 3 \\
\text { Skinny Minnies is familiar to } \\
\text { me }\end{array}$ & \\
\hline
\end{tabular}




\begin{tabular}{|c|c|c|c|}
\hline & Similar & $\begin{array}{l}\text { I perceive myself similar (in } \\
\text { terms of values, styles, etc) with } \\
\text { the celebrity endorser of } 3 \\
\text { Skinny Minnies }\end{array}$ & \\
\hline \multirow{7}{*}{$\begin{array}{l}\text { Celebrity } \\
\text { Endorser's } \\
\text { Credibility }\end{array}$} & Honest & $\begin{array}{l}\text { I have impression that the } \\
\text { celebrity endorser (Dian Sastro) } \\
\text { of } 3 \text { Skinny Minnies possess } \\
\text { honesty in endorses the product }\end{array}$ & \multirow{7}{*}{$\begin{array}{l}\text { Ohanian (1990) } \\
\text { as cited in } \\
\text { Kutthakaphan \& } \\
\text { Chokesamritpol } \\
\text { (2013); Muda et } \\
\text { al., (2014) }\end{array}$} \\
\hline & Sincere & $\begin{array}{l}\text { I have impression that the } \\
\text { celebrity endorser of } 3 \text { Skinny } \\
\text { Minnies possess sincerity in } \\
\text { endorses the product }\end{array}$ & \\
\hline & Trustworthy & $\begin{array}{l}\text { I have impression that the } \\
\text { celebrity endorser of } 3 \text { Skinny } \\
\text { Minnies possess trustworthy in } \\
\text { endorses the product }\end{array}$ & \\
\hline & Reliable & $\begin{array}{l}\text { I have impression that the } \\
\text { celebrity endorser of } 3 \text { Skinny } \\
\text { Minnies possess reliability in } \\
\text { endorses the product }\end{array}$ & \\
\hline & Qualified & $\begin{array}{l}\text { I have impression that the } \\
\text { celebrity endorser of } 3 \text { Skinny } \\
\text { Minnies is qualified person to } \\
\text { be the endorsee of } 3 \text { Skinny } \\
\text { Minnies brand }\end{array}$ & \\
\hline & Experienced & $\begin{array}{l}\text { I have impression that the } \\
\text { celebrity endorser of } 3 \text { Skinny } \\
\text { Minnies is exprienced person in } \\
\text { living a healthy life style }\end{array}$ & \\
\hline & Knowledgeable & $\begin{array}{l}\text { I have impression that the } \\
\text { celebrity endorser of } 3 \text { Skinny } \\
\text { Minnies possess knowledge of } \\
\text { the endorsed product }\end{array}$ & \\
\hline \multirow{3}{*}{$\begin{array}{l}\text { Celebrity and } \\
\text { Product } \\
\text { Congruence }\end{array}$} & Conformity & $\begin{array}{c}\text { I think the celebrity endorser is } \\
\text { best fit to represent } 3 \text { Skinny } \\
\text { Minnies. }\end{array}$ & $\begin{array}{l}\text { Kutthakaphan \& } \\
\text { Chokesamritpol } \\
\text { (2013) }\end{array}$ \\
\hline & $\begin{array}{l}\text { Celebrity - } \\
\text { Product } \\
\text { Association }\end{array}$ & $\begin{array}{l}\text { I easily related the celebrity } \\
\text { endorser with the brand of } 3 \\
\text { Skinny Minnies (think of } 3 \\
\text { Skinny Minnies when thinking } \\
\text { about the celebrity) }\end{array}$ & $\begin{array}{l}\text { Löfgren \& Li } \\
\qquad(2010)\end{array}$ \\
\hline & Matching Image & $\begin{array}{c}\text { The image of the celebrity with } \\
3 \text { Skinny Minnies brand is } \\
\text { match and congruence }\end{array}$ & $\begin{array}{l}\text { Choi \& Rifon } \\
\text { (2012) }\end{array}$ \\
\hline
\end{tabular}




\begin{tabular}{|c|c|c|c|}
\hline \multirow{5}{*}{$\begin{array}{l}\text { Attitude } \\
\text { toward the } \\
\text { Brand }\end{array}$} & High Quality & $\begin{array}{l}\text { By seeing the Instagram post } \\
\text { from celebrity endorser's } \\
\text { account, I have impression that } \\
3 \text { Skinny Minnies brand } \\
\text { provides high quality products }\end{array}$ & $\begin{array}{l}\text { Martines et al., } \\
\text { (2009); Sattler } \\
\text { et al., (2010); } \\
\text { Shahrokh } \\
\text { (2012) }\end{array}$ \\
\hline & Good & $\begin{array}{l}\text { By seeing the Instagram post } \\
\text { from celebrity endorser's } \\
\text { account, I have impression that } \\
3 \text { Skinny Minnies brand is good }\end{array}$ & $\begin{array}{c}\text { Martines et al., } \\
\text { (2009); Person } \\
\text { (2010); } \\
\text { Shahrokh } \\
\text { (2012); Choi \& } \\
\text { Rifon (2012) } \\
\end{array}$ \\
\hline & Favorable & $\begin{array}{l}\text { By seeing the Instagram post } \\
\text { from celebrity endorser's } \\
\text { account, I have impression that } \\
3 \text { Skinny Minnies brand is } \\
\text { favorable }\end{array}$ & $\begin{array}{c}\text { Colucci et al., } \\
\text { (2008); } \\
\text { Martines et al., } \\
\text { (2009); } \\
\text { Shahrokh } \\
\text { (2012); Choi \& } \\
\text { Rifon (2012) }\end{array}$ \\
\hline & Likeability & $\begin{array}{l}\text { After seeing the Instagram post } \\
\text { from celebrity endorser's } \\
\text { account, I like } 3 \text { Skinny Minnies } \\
\text { brand }\end{array}$ & $\begin{array}{c}\text { Martines et al., } \\
\text { (2009); Sattler } \\
\text { et al., (2010); } \\
\text { Shahrokh } \\
\text { (2012); Choi \& } \\
\text { Rifon (2012) }\end{array}$ \\
\hline & Pleasant & $\begin{array}{l}\text { By seeing the instagram post } \\
\text { from celebrity endorser's } \\
\text { account, I have impression that } \\
\text { consuming } 3 \text { Skinny Minnies } \\
\text { healthy food dietary give } \\
\text { pleasant feeling }\end{array}$ & $\begin{array}{c}\text { Choi \& Rifon } \\
\text { (2012) }\end{array}$ \\
\hline \multirow{5}{*}{$\begin{array}{l}\text { Purchase } \\
\text { Intention }\end{array}$} & Interest & $\begin{array}{l}\text { I have interest to purchase } 3 \\
\text { Skinny Minnies Product }\end{array}$ & $\begin{array}{l}\text { Yuanwen Zeng, } \\
\text { (2008) }\end{array}$ \\
\hline & Prediction & $\begin{array}{c}\text { If there is an opportunity, I } \\
\text { predict that I should purchase } 3 \\
\text { Skinny Minnies product in the } \\
\text { future }\end{array}$ & $\begin{array}{c}\text { Choon Ling } \\
\text { Kwek, (2010) }\end{array}$ \\
\hline & Value & $\begin{array}{l}\text { This product has a good value } \\
\text { and worth to purchase }\end{array}$ & Bredhal, (2000) \\
\hline & $\begin{array}{l}\text { Purchase } \\
\text { Probability }\end{array}$ & $\begin{array}{c}\text { If I given a chance to purchase } \\
\text { diet program menu from } 3 \\
\text { Skinny Minnies, I would } \\
\text { definetely buy it. }\end{array}$ & $\begin{array}{c}\text { Yuanwen Zeng, } \\
\quad(2008)\end{array}$ \\
\hline & Intention & $\begin{array}{l}\text { I am willing to purchase } 3 \\
\text { Skinny Minnies Product }\end{array}$ & $\begin{array}{l}\text { Mitchel and } \\
\text { Ring, (2010) }\end{array}$ \\
\hline
\end{tabular}

\section{Hypothesis Testing}


Proposed hypothesis of the research will be analyzed by regression weight analysis of structural equation modeling (SEM) measurement where the acceptance criteria in regression weight analysis are the critical value should be more than 1.96 (>1.96), and p - significant value should be less than $0.05(\mathrm{P}<0.05)$ and the hypothesis is accepted if it passes minimum criteria of regression weight analysis. Meanwhile, influential percentage between independent variable and dependent variable were measured from standardized regression weight. Hypothesis testing is formulated in terms of two hypotheses, which are the null hypothesis and the alternate hypothesis where alternate hypothesis assumed to be true unless there is strong contrary evidence. In the other hand, the null hypothesis is assumed to be true when the null hypotheses are false.

H1a: Celebrity endorser's attractiveness has influence on attitude toward the brand on Instagram.

H1o: Celebrity endorser's attractiveness has no influence on attitude toward the brand on Instagram.

H2a: Celebrity endorser's attractiveness has influence on purchase intention.

H2o: Celebrity endorser's attractiveness has no influence on purchase intention.

H3a: Celebrity endorser's credibility has influence on attitude toward the brand on Instagram.

H3o: Celebrity endorser's credibility has no influence on attitude toward the brand on Instagram.

H4a: Celebrity endorser's credibility has influence on purchase intention.

H4o: Celebrity endorser's credibility has no influence on purchase intention.

H5a: Celebrity endorser and product congruency has influence on attitude toward the brand on Instagram.

H5o: Celebrity endorser and product congruency has no influence on attitude toward the brand on Instagram.

H6a: Celebrity endorser and product congruency has influence on purchase intention. 
H6o: Celebrity endorser and product congruency has no influence on purchase intention.

H7a: Attitude toward the brand has influence on purchase intention.

H7o: Attitude toward the brand has no influence on purchase intention.

\section{Result and Discussion}

\section{Respondent's Profile}

Researcher, in conducting this research has achieved to gather 274 responses from respondents through questionnaire, demographic data of respondents are gender ( $78 \%$ female, $22 \%$ male), age (57\% of $18-22$ years old, $24 \%$ of $23-28$ years old, $19 \%$ of $29-35$ years old) occupation (62\% student, $17 \%$ employee, $13 \%$ entrepreneur, $1 \%$ academics, $1 \%$ professional, and $6 \%$ other occupation), education (58\% pursuing undergraduate, $26 \%$ undergraduate, $8 \%$ pursuing post graduate, $6 \%$ post graduate, and $2 \%$ high school graduate), income (38\% above Rp. 4,000,000, 32\% below Rp. 2,500,000, 12\% between Rp. 2,500,000-Rp. 3,000,000, 10\% between Rp. 3,500,000 - Rp. 4,000,000 and 8\% between Rp. 3,000,000 - Rp. 3,500,000), interest in health food ( $90 \%$ interested, $10 \%$ not interested), Experience in trying healthy food ( $86 \%$ yes, $14 \%$ no), frequency in accessing Instagram (80\% every day, 12\% 3-5 days in a week, 6\% once a week, and $2 \%$ less than once in a week), following account of favorite celebrity (93\% yes, $7 \%$ no). Based on the demographic data collected, it is conclude that Instagram is good for promotional channel in advertising product through social media. Utilizing Instagram for business also can reduce the budget of promotion in reaching the customers by using celebrity endorsement strategy.

\section{Data Analysis}

In this research, variables which passed validity and reliability analysis will be proceeded to structural equation modeling (SEM). The use of SEM analysis is to test the correctness of theoretical framework and hypothesis proposed by this research. Several assessments needed to be done before the analysis of hypothesis. There are five variables included in this research that categorized into there types variables. The independent variables consists of celebrity endorser's attractiveness, celebrity endorser's credibility and celebrity and product congruence. The mediator variable is attitude toward the brand. Purchase intention serves as dependent variable. Figure 2 will show the path diagram and resut of the standardized estimates calculation of SEM 
Figure 2. Standardized Estimates Calculation of SEM (Proposed Model)

Source: Statistical software result

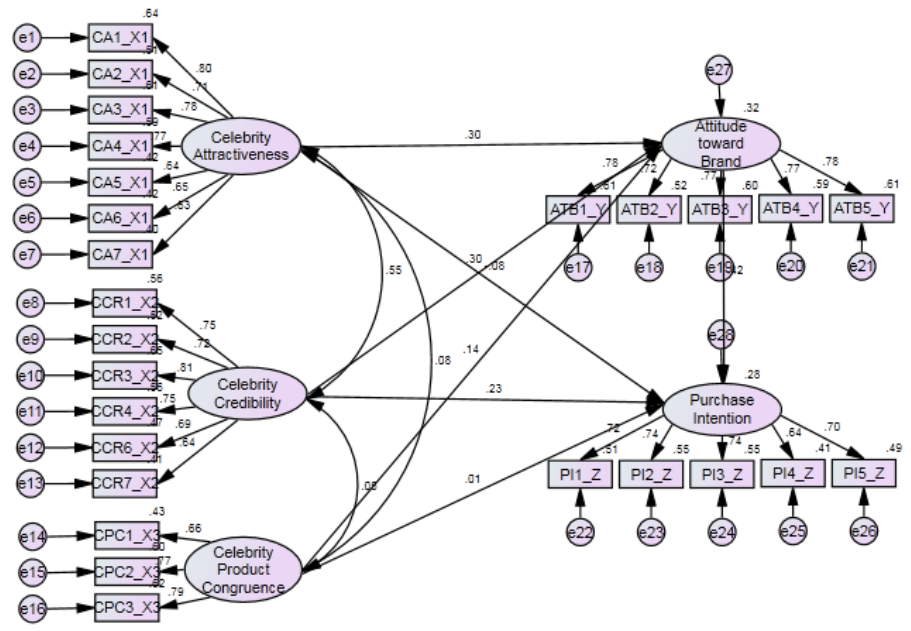

Table 2 is the result of standardized effect, it helps researcher to evaluate the influence of each variables both direct and indirect. Based on the table 2, Customer's Attitude toward the Brand is found to be most significantly and directly influence by Celebrity Endorser's Attractiveness by 30.4\%, followed by Celebrity Endorser's Credibility by $30.3 \%$, and Celebrity and Product Congruence by $14.1 \%$. There is no indirect effect from any variable is found.

Purchase intention as dependent variable is affected by other variables in direct or indirect way. From independent variables, celebrity and product congruence has $1.1 \%$ direct effect and $5.9 \%$ indirect effect influence on purchase intention. Celebrity endorser's credibility has $23.2 \%$ direct effect and $12.7 \%$ indirect effect on purchase intention. Celebrity endorser's attractiveness has negative direct effect $(-8.2 \%)$, meanwhile it has $12.8 \%$ indirect effect toward purchase intention. In total, Celebrity and Product Congruence has 7\%, Celebrity Credibility has 36\%, and Celebrity Attractiveness has $4.6 \%$ total effect on Purchase Intention. The most influencing variable toward purchase intention is which is $42.1 \%$.

Table 2. Standardized Effect Source: Statistical software

\begin{tabular}{|c|c|c|c|c|c|}
\hline \multicolumn{6}{|c|}{ Standardized Total Effects } \\
\hline & $\begin{array}{l}\text { Celebrity \& } \\
\text { Product }\end{array}$ & $\begin{array}{l}\text { Celebrity's } \\
\text { Credibility }\end{array}$ & $\begin{array}{c}\text { Celebrity's } \\
\text { Attractiveness }\end{array}$ & \begin{tabular}{|c|} 
Attitude \\
toward the
\end{tabular} & $\begin{array}{l}\text { Purchase } \\
\text { Intention }\end{array}$ \\
\hline $\begin{array}{c}\text { Attitude } \\
\text { toward the } \\
\text { Brand }\end{array}$ & 0.141 & 0.303 & 0.304 & 0.000 & 0.000 \\
\hline $\begin{array}{l}\text { Purchase } \\
\text { Intention }\end{array}$ & 0.070 & 0.360 & 0.046 & 0.421 & 0.000 \\
\hline \multicolumn{6}{|c|}{$\begin{array}{ll}\text { Standardize Direct Effects } \\
\end{array}$} \\
\hline & $\begin{array}{l}\text { Celebrity \& } \\
\text { Product } \\
\text { Congruence }\end{array}$ & $\begin{array}{l}\text { Celebrity's } \\
\text { Credibility }\end{array}$ & $\begin{array}{c}\text { Celebrity's } \\
\text { Attractiveness }\end{array}$ & $\begin{array}{c}\text { Attitude } \\
\text { toward the } \\
\text { Brand }\end{array}$ & $\begin{array}{l}\text { Purchase } \\
\text { Intention }\end{array}$ \\
\hline $\begin{array}{c}\text { Attitude } \\
\text { toward the } \\
\text { Brand }\end{array}$ & 0.141 & 0.303 & 0.304 & 0.000 & 0.000 \\
\hline $\begin{array}{l}\text { Purchase } \\
\text { Intention }\end{array}$ & 0.011 & 0.232 & -0.082 & 0.421 & 0.000 \\
\hline \multicolumn{6}{|c|}{ Standardized Indirect Effects } \\
\hline & $\begin{array}{l}\text { Celebrity \& } \\
\text { Product } \\
\text { Congruence }\end{array}$ & $\begin{array}{l}\text { Celebrity's } \\
\text { Credibility }\end{array}$ & $\begin{array}{c}\text { Celebrity's } \\
\text { Attractiveness }\end{array}$ & $\begin{array}{c}\text { Attitude } \\
\text { toward the } \\
\text { Brand }\end{array}$ & $\begin{array}{l}\text { Purchase } \\
\text { Intention }\end{array}$ \\
\hline $\begin{array}{c}\text { Attitude } \\
\text { toward the } \\
\text { Brand }\end{array}$ & 0.000 & 0.000 & 0.000 & 0.000 & 0.000 \\
\hline $\begin{array}{l}\text { Purchase } \\
\text { Intention }\end{array}$ & 0.059 & 0.127 & 0.128 & 0.000 & 0.000 \\
\hline
\end{tabular}
attitude toward the brand

result 


\section{Interpretation of Result}

Based on table 2, shows that independent variables have direct effect on attitude toward the brand, while only celebrity's endorser credibility that has an influence toward purchase intention. Celebrity endorser's attractiveness found to be the most significant factor, which directly influence customer's attitude toward the brand of 3 Skinny Minnies but it does not have any significant effect on purchase intention. Ahmed et al., (2012) on previous research stated that celebrity endorser's attractiveness will influence a good impression of customers' toward the endorsed product. Meanwhile, Oyeniyi (2014) and Hasan \& Jamil (2014) stated that there is no influence between celebrity endorser's attractiveness and customers' in making direct purchase decision. Therefore, celebrity endorsers' attractiveness does not have significant influence toward purchase intention. Another independent variable, celebrity endorser's credibility found to have influence on attitude toward the brand. This finding is similar with previous research by Muda et al (2014). Celebrity endorser's credibility also found to have a direct effect on purchase intention, similar with previous researches by Kumar (2010), Nhung et al. (2011), and Ahmed et al. (2014). Celebrity endorser's and product congruence as independent variable also found to have significant direct effect on attitude toward the brand. However, this finding is not represent similar result compare to previous research conducted by Choi \& Rifon (2012) who stated that celebrit and product congruence does not have direct on attitude toward the brand. The difference in findings might be caused by different object of study and additional variable as mediator that used by previous research. However, similar with previous research by Choi \& Rifon (2012), Celebrity Endorser's and Product Congruence has negative influence toward Purchase Intention. 
Lastly, based on this research, it is found that customer's purchase intention is significantly influenced by attitude toward the brand in direct manner. Previous research by Wahid \& Ahmed (2011); Nunnelley (2012); Choi \& Rifon (2012); and Muda et al. (2014) also has same result with this research. Attitude toward the brand is proven as mediation variable between celebrity endorsement effectiveness and purchase intention. Thus, if customers have positive impression toward the endorsed product, it will lead to favorable purchase intention.

\section{E. Conclusion and Implications}

\section{Conclusion}

Based on the hypothesis testing through structural equation modeling (SEM) analysis, it is shown that all independent variables (celebrity endorser's attractiveness, celebrity endorser's credibility, and celebrity's endorser product congruence) are highly influencing the mediator variable (attitude toward the brand). However, it is only celebrity's endorsers credibility as indicator from independent variables that has significant influence toward purchase intention. Attitude toward the brand is the most influencing variable in order to lead the customer purchase intention, Thus, in order to create a good impression toward the brand, celebrity endorsement is one of the strategies that can be utilized. Celebrity endorsement also found to has significant direct effect on the attitude toward the brand.

\section{Managerial Implications}

Based on the research analysis, celebrity endorser does not significantly improve customers purchase intention to 3 Skinny Minnies product. In the other hand, purchase intention is significantly influenced by the mediator variable, which is attitude toward the brand. Moreover, attitude toward the brand is most influenced by celebrity attractiveness. Thus, 3 Skinny Minnies has successfully created customer awareness and positive feeling toward the brand through attractiveness that possessed by Dian Sastro Wardoyo as celebrity endorser.

Celebrity credibility has a significant direct effect on purchase intention and serve as the only variable for that matters in this research. Meanwhile, image congruence between celebrity and 3 Skinny Minnies product has low influence in driving customer to purchase the product. In the other words, since Dian Sastro Wardoyo has already become brand ambassador for several products from beauty to gadget products. Thus, celebrity's credibility that established by having Dian Sastro Wardoyo as 3 Skinny Minnies endorser does not perform well since it is a negative 
sides of celebrity endorsement strategy for celebrity endorser to be overexposed by endorsing many brands.

3 Skinny Minnies has quite expensive price for its package with range from Rp.1,500,000 to Rp.1,750,000 for 5 days meals exclude delivery service charge. In order to continue celebrity endorsement strategy, it is important to have celebrity endorser who really can represents such credibility that expected by potential customers of 3 Skinny Minnies. Not only actress as Dian Sastro Wardoyo, celebrity chef and famous food blogger can also become celebrity endorser for 3 Skinny Minnies in order to create strong message of healthy food diet and increasing customer believability that lead to purchase intention for 3 Skinny Minnies product. Customer relationship is also important to be maintained by providing proactive customer service or embedding delivery service into the package.

\section{Future Research}

Future research may evaluate other relevance variables, which able to affect customers' attitude toward the brand, and purchase intention to enrich research findings. Future research are suggested to combine qualitative and quantitative research in purpose to compare the data that obtained from both approaches. Finally, increasing number of sample size can also be done in future research to sharpen the assurance of data and ore reliable result.

\section{References}

Belch, G. E., \& Belch, M. A. (2003). Advertising and Promotion: An Integrated Marketing Communications Perspective (6th ed.). Boston: McGraw-Hill

Keller, K. L. (2013). Strategic Brand Management: Building, Measuring, and Managing Brand Equity (4th ed.). England: Pearson Education Limited.

Kothari, C. R. (2004). Research Methodology, Methods and Techniques (2nd ed.). New Delhi: New Age International Publisher.

Malhotra, N. K., Birks, D. F., \& Wills, P. (2010). Marketing research: An applied approach. Harlow: Pearson Education.

Shimp, T. A. (2010). Advertising, Promotion and Other Aspects of. Integrated Marketing Communications (8th ed.). Mason: South-Western/Cengage Learning.

Kumar, A. (2010). Celebrity Endorsements and Its Impact on Consumer Buying Behavior. Master Thesis. The Executive Business School: Bournemouth University, India. 
Kutthakaphan, R. (2013). The Use of Celebrity Endorsement with the Help of Electronic Communication Channel (Instagram): Case study of Magnum Ice Cream in Thailand. Master's thesis, Mälardalen University School of Business, Society and Engineering, Thailand.

Löfgren, E., \& Li, J. (2010). Brand Loyalty: A Study of the Prevalent Usage of Celebrity Endorsement in Cosmetics Advertising Master's thesis, Umeå School of Business, Sweden.

Mangan, J. (2013). A Quantitative Study of the Effect of Celebrity Endorsers on Consumer Purchase Intent. Master Thesis. National College of Ireland, Ireland.

Nhung, N. P. (2011). Effectiveness of Consumer Endorser in Social Media Advertisement: Impact on consumers' attitudes and behaviors. Master's Thesis. Retrieved from ProQuest Dissertations and Theses database.

Choi, S. M., \& Rifon, N. J. (2012). It Is a Match: The Impact of Congruence between Celebrity Image and Consumer Ideal Self on Endorsement Effectiveness. Psychology \& Marketing, 29(9), 639-650. doi:10.1002/mar.20550

Doss, S. (2011). The Transference of Brand Attitude: The Effect on The Celebrity Endorser. Journal of Management and Marketing Research, 7, 1-11.

Erdogan, B. Z. (1999). Celebrity Endorsement: A Literature Review. Journal of Marketing Management, 15(4), 291-314. doi:10.1362/026725799784870379

McCracken, G. (1989). Who is the Celebrity Endorser? Cultural Foundations of the Endorsement Process. Journal of Consumer Research, 16(3), 310. doi:10.1086/209217

Muda, M., Musa, R., Mohamed, R. N., \& Borhan, H. (2014). Celebrity Entrepreneur Endorsement and Advertising Effectiveness. Procedia - Social and Behavioral Sciences, 130, 11-20.

Neti, S. (2011). Social Media and its Role in Marketing. International Journal of Enterprise Computing and Business Systems, 1(2).

Ohanian, R. (1990). Construction and Validation of a Scale to Measure Celebrity Endorsers' Perceived Expertise, Trustworthiness, and Attractiveness. Journal of Advertising, 19(3), 39-52. doi:10.1080/00913367.1990.10673191

Oyeniyi, O. (2014). Celebrity Endorsements and Product Performance: A Study of Nigerian Consumer Markets. Management\&Marketing, 12(1).

Spears, N., \& Singh, S. N. (2004). Measuring Attitude toward the Brand and Purchase Intentions. Journal of Current Issues \& Research in Advertising, 26(2), 53-66. doi:10.1080/10641734.2004.10505164 
Adani, S. (2015). Effect of Celebrity Endorsement on Purchase Intention and the Intercourse with Customer Satisfaction in Local Brand (Case Study: The use of Ask.fm artist by We Are the Walrus). International Conference on Trends in Social Sciences and Humanities.

blog.jakpat.net. (2017, May 20). Indonesia Social Media Habit Report Q1 2017. Retrieved on August $3^{\text {rd }} 2017$ blog.jakpat.net: https://blog.jakpat.net

Straitstimes (n,d). Indonesia in top five for countries with diabetes: WHO, SE Asia News \& Top Stories - The Straits Times. Retrieved on November $11^{\text {th }} 2016$ http://www.straitstimes.com/asia/se-asia/indonesia-in-top-five-for-countries-withdiabetes-who

WHO. (n.d.). Country and regional data on diabetes. Retrieved on November $11^{\text {th }} 2016$ http://www.who.int/diabetes/facts/world_figures/en/index5.html

Worldlifeexpentancy. (n.d.). Diabetes Mellitus in Indonesia. Retrieved on November $11^{\text {th }} 2016$ http://www.worldlifeexpectancy.com/indonesia-diabetes-mellitus 
